DOI: https://doi.org/10.24127/ajpm.v9i4.3185

\title{
PENGARUH MODEL PEMBELAJARAN MISSOURI MATHEMATICS PROJECT TERHADAP KEMAMPUAN PEMECAHAN MASALAH MATEMATIS DITINJAU DARI KEMAMPUAN VERBAL
}

\author{
Ahmad Muhaimin ${ }^{1}$, Zubaidah Amir MZ \\ ${ }^{1,2}$ Pendidikan Matematika, UIN Sultan Syarif Kasim Riau, Indonesia \\ *Corresponding author \\ E-mail: $\quad$ 11515103953@students.uin-suska.ac.id ${ }^{1)}$ \\ $\underline{\text { Zubaidah.amir@uin-suska.ac.id }}^{2)}$
}

Received 21 October 2020; Received in revised form 12 December 2020; Accepted 27 December 2020

\begin{abstract}
Abstrak
Penelitian ini bertujuan untuk mengetahui ada tidaknya pengaruh model pembelajaran Missouri Mathematics Project (MMP) terhadap kemampuan pemecahan masalah matematis ditinjau dari kemampuan verbal siswa kelas VIII SMP Negeri 20 Pekanbaru tahun ajaran 2019/2020. Penelitian ini merupakan penelitian eksperimen dengan menggunakan desain Factorial Design. Populasi dalam penelitian ini adalah seluruh siswa kelas VIII, dan sampelnya adalah siswa kelas VIII.1 dan VIII.4 yang masing-masing berjumlah 35 siswa, sampel yang diperoleh diambil dengan menggunakan teknik Cluster Sampling. Adapun bentuk instrumen yang digunakan adalah tes objektif pilihan ganda untuk mengukur kemampuan verbal siswa dan tes uraian untuk mengukur kemampuan pemecahan masalah matematis. Sedangkan teknik analisis data menggunakan uji Anova dua arah. Hasil analisis data menunjukkan $\mathrm{F}_{(\mathrm{A}) \text { hitung }}=17,08>\mathrm{F}_{(\mathrm{A}) \text { tabel }}=3,14 ; \mathrm{F}_{(\mathrm{B}) \text { hitung }}=11,59>\mathrm{F}_{(\mathrm{B}) \text { tabel }}=3,99 ;$ dan $\mathrm{F}_{(\mathrm{AxB}) \text { hitung }}=-0,65<\mathrm{F}_{(\mathrm{AXB}) \text { tabel }}=$ 3,14. Sehingga diperoleh kesimpulan hasil penelitian bahwa: 1) Terdapat pengaruh yang positif dan signifikan model pembelajaran Missouri Mathematics Project (MMP) terhadap kemampuan pemecahan masalah matematis siswa, 2) Terdapat pengaruh kemampuan verbal terhadap kemampuan pemecahan masalah matematis siswa, 3) Tidak terdapat interaksi antara model pembelajaran dan kemampuan verbal terhadap kemampuan pemecahan masalah matematis siswa.
\end{abstract}

Kata kunci: Kemampuan Pemecahan Masalah; Kemampuan Verbal; Missouri Mathematics Project.

\begin{abstract}
This research aimed at knowing the effect of missouri mathematics project (MMP) learning model toward students' mathematic problem-solving ability derived from their verbal ability at the eighth-grade of State Junior High School 20 Pekanbaru in the Academic Year of 2019/2020. It was an experimental research with Factorial design. All the eighth-grade students were the population of this research, and the samples were the students of classes 1 and 4 selected each of which totaled 35 students, the sample obtained was taken using Cluster Sampling technique. The instruments used were multiple choice test to measure student verbal ability and essay tests to measure mathematic problem solving ability. Techniques of analyzing the data were two-way Anova. The results of the data analysis show $F_{(A)}=17,08>F_{(A) t a b l e}=$ 3,14; $F_{(B)}=11,59>F_{(B) t a b l e}=3,99 ;$ and $F_{(A x B)}=-0,65<F_{(A x B) t a b l e}=3,14$. So that the conclusions obtained from the research results that: 1) there is a positive and significant influence on the missouri mathematics project (MMP) learning model on students' mathematic problem solving abilities, 2) there is an influence of verbal ability on the ability to solve mathematic problems, 3) there is no interaction between learning models and verbal abilities on students' mathematic problem solving abilities.
\end{abstract}

Keywords: Missouri Mathematics Project; Problem Solving Ability; Verbal Ability.

This is an open access article under the Creative Commons Attribution 4.0 International License 
DOI: https://doi.org/10.24127/ajpm.v9i4.3185

\section{PENDAHULUAN}

Matematika merupakan pelajaran yang selalu ada disetiap jenjang pendidikan. Pentingnya mempelajari matematika sudah diajarkan pada anak sejak usia dini, bahkan sejak Taman kanan-kanak, anak-anak sudah diajarkan untuk mengenal angka dan berhitung. Selain itu juga konsep matematika selalu ada diberbagai bidang pelajaran, bahkan ilmu matematika sangat bermanfaat dalam kehidupan sehari-hari. Ini menunjukkan bahwa pentingnya matematika untuk dipelajari bahkan menjadi salah satu pelajaran yang ditetapkan sebagai standar kelulusan.

Salah satu kemampuan yang sangat diharapkan untuk dikuasai siswa dalam pembelajaran matematika adalah kemampuan pemecahan masalah. Hal ini berdasarkan pernyataan bahwa pemecahan masalah matematis: 1) merupakan kemampuan yang tercantum dalam kurikulum dan tujuan pembelajaran matematika 2) meliputi metode, prosedur dan strategi sebagai proses inti dan utama dalam kurikulum, tujuan umum pembelajaran matematika, bahkan sebagai jantungnya matematika (Hendriana, Rohaeti, \& Sumarmo, 2017).

Namun melihat permasalahan yang terjadi saat ini banyaknya siswa yang memiliki kemampuan pemecahan masalah matematis yang rendah. Faktanya berdasarkan hasil The Programme for International Student Assessment (PISA) tahun 2018, bahwa untuk skor rata-rata matematika mencapai 379 dengan skor rata-rata OECD 487 (Kemdikbud, 2019). Sedangkan pada tahun 2015 yang lalu Indonesia memperoleh skor rata-rata 386 lebih baik dari tahun 2018. Ini menunjukkan adanya penurunan performa hasil PISA dari tahun sebelumnya. Item yang diuji dalam test PISA ini memadukan antara proses pemecahan masalah dengan kolaborasi kompetensi pemecahan masalah yang dinilai dalam empat rentang score kemampuan (Pembelajaran, 2019).

Fakta lainnya dari hasil studi pendahuluan kemampuan pemecahan masalah matematis siswa kelas VIII SMP di Pekanbaru, diperoleh bahwa persentase kegagalan siswa dalam memecahkan masalah $(60 \%)$ yang lebih tinggi dari pada persentase keberhasilannya (40\%). Apabila permasalahan ini dibiarkan terus menerus maka prestasi belajar matematika siswa akan menjadi buruk.

Rendahnya kemampuan siswa dalam memecahkan masalah matematis ini dipengaruhi oleh penerapan model pembelajaran yang tidak sesuai dengan tujuan pembelajaran sehingga pembelajaran menjadi tidak efektif. Pembelajaran efektif yang dimaksud merupakan pembelajaran yang melibatkan seluruh siswa untuk berperan aktif. Hal ini disebabkan karena guru masih menerapkan model pembelajaran langsung yang fokusnya hanya berpusat pada guru, siswa hanya sebagai pendengar yang pasif dan tidak adanya diskusi kelompok. Sehingga kurangnya kreatifitas untuk meningkatkan kemampuan siswa dalam memecahkan masalah matematis.

Salah satu model pembelajaran yang berupaya membuat siswa berperan aktif dan meningkatkan kemampuan pemecahan masalah matematisnya adalah model Missouri Mathematics Project (MMP). Hal ini senada dikemukakan oleh Ansori dan Aulia bahwa model MMP adalah salah satu model pembelajaran yang mampu meningkatkan kemampuan siswa dalam memecahkan masalah matematis (Ansori \& Aulia, 2015). 
DOI: https://doi.org/10.24127/ajpm.v9i4.3185

Model pembelajaran MMP merupakan suatu program yang di desain untuk membantu guru dalam hal efektivitas penggunaan lembar tugas proyek agar siswa mencapai peningkatan yang luar biasa (Wulandari \& Ansori, 2013). Adapun tugas proyek yang dimaksud yaitu berupa latihanlatihan pada tugas kelompok dan tugas mandiri. Langkah-langkah kegiatan dari penerapan model pembelajaran MMP yaitu 1) Pendahuluan atau Review, 2) Pengembangan, 3) Latihan dengan bimbingan guru, 4) Kerja mandiri, dan 5) Penutup (Tiasto \& Arliani, 2015).

Fokus guru dalam menerapkan model ini adalah melatih siswa untuk menyelesaikan latihan soal secara mandiri dan berkelompok agar siswa bisa terampil dalam memecahkan masalah matematis. Untuk dapat memperoleh kemampuan pemecahan masalah, seseorang itu harus memiliki pengalaman dalam memecahkan berbagai masalah (Gafur, Sudia, \& Hasnawati, 2015). Seperti hasil penelitian terdahulu yang menyatakan bahwa model pembelajaran MMP berpengaruh positif dan signifikan terhadap kemampuan pemecahan masalah matematika (Rahmiati \& Fahrurrozi, 2016).

Zubaidah dan Riska menyatakan bahwa kemampuan pemecahan masalah matematis merupakan tolak ukur dalam menyelesaikan soal matematika dan menjadi fokus pembelajaran matematika disemua jenjang pendidikan (Riska \& Amir, 2018). Terdapat empat langkah penting yang harus dilakukan siswa dalam memecahkan masalah, yaitu: 1) memahami masalah, 2) merencanakan penyelesaian, 3) menyelesaikan masalah, dan 4) memeriksa kembali. Dari keempat langkah proses pemecahan masalah tersebut, tugas guru sebagai tenaga pendidik adalah membantu, mengontrol, memfasilitasi dan mengajarkan siswa untuk menyelesaikan suatu masalah secara terstruktur dengan melaksanakan langkah-langkah dari pemecahan masalah tersebut.

Salah satu faktor lainnya yang menjadi penyebab kelemahan siswa dalam menyelesaikan masalah matematis yaitu siswa tidak memahami maksud dari soal/ masalah yang diberikan (Komariya, Farida, \& Vahlia, 2018). Dimana kemampuan yang dimaksud ini adalah kemampuan verbal. Seperti yang dikemukakan oleh James dan Adewale bahwa kemampuan pemecahan masalah matematis ada hubungannya dengan kemampuan verbal siswa (James \& Adewale, 2010).

Kemampuan verbal merupakan kemampuan yang dimiliki seseorang untuk menjelaskan pemikirannya dan mengaitkan informasi yang diperolehnya serta dapat membuat suatu hipotesis (Irawan \& Kencanawaty, 2016). Dalam matematika terdapat berbagai istilah-istilah berupa symbol, angka dan bahasa matematika yang tentunya harus dipahami oleh siswa ketika mempelajari matematika. Wahyuddin menyatakan bahwa terdapat pengaruh positif kemampuan verbal terhadap kemampuan menyelesaikan soal cerita, dengan besar pengaruhnya $42 \%$, sedangkan sisanya dipengaruhi oleh variabel lain (Wahyuddin, 2016).

Adapun komponen-komponen dari kemampuan verbal ini terdiri dari pemahaman verbal dan perbendaharaan kata (Wahyuddin, 2016). Komponen kemampuan verbal merupakan suatu aspek atau indikator yang ada dalam bahasa verbal, sehingga komponen ini merupakan indikator yang digunakan untuk mengukur kemampuan verbal siswa. 
Penelitian ini bertujuan untuk mengetahui: 1) ada tidaknya pengaruh penerapan model pembelajaran terhadap kemampuan pemecahan masalah matematis (KPMM) siswa, 2) ada tidaknya pengaruh kemampuan verbal terhadap KPMM siswa, 3) ada tidaknya interaksi antara model pembelajaran dan kemampuan verbal terhadap KPMM siswa.

\section{METODE PENELITIAN}

Jenis penelitian ini merupakan penelitian eksperimen dengan menggunakan desain Factorial Design. Desain penelitian ini menggunakan dua kelompok sampel, yaitu kelas eksperimen menggunakan model pembelajaran MMP dan kelas kontrol menggunakan model pembelajaran langsung. Rancangan eksperimen data posttest dalam penelitian ini menggunakan desain faktorial $2 \times 3$ yang disajikan pada Tabel 1 .

Tabel 1. Desain faktorial data posttest.

\begin{tabular}{cccc}
\hline \multirow{2}{*}{ Model Pembelajaran } & \multicolumn{3}{c}{ Kemampuan Verbal } \\
\cline { 2 - 4 } & $\left(\mathrm{A}_{1}\right)$ & $\left(\mathrm{A}_{2}\right)$ & $\left(\mathrm{A}_{3}\right)$ \\
\hline Missouri Mathematics Project $\left(\mathrm{B}_{1}\right)$ & $\mathrm{A}_{1} \mathrm{~B}_{1}$ & $\mathrm{~A}_{2} \mathrm{~B}_{1}$ & $\mathrm{~A}_{3} \mathrm{~B}_{1}$ \\
Pembelajaran langsung $\left(\mathrm{B}_{2}\right)$ & $\mathrm{A}_{1} \mathrm{~B}_{2}$ & $\mathrm{~A}_{2} \mathrm{~B}_{2}$ & $\mathrm{~A}_{3} \mathrm{~B}_{2}$ \\
\hline
\end{tabular}

Penelitian ini terdiri dari beberapa variabel yang digunakan, variabel bebas yaitu model pembelajaran Missouri Mathematics Project ( $\left.\mathrm{B}_{1}\right)$, variabel terikat yaitu kemampuan pemecahan masalah dan variabel moderator yaitu kemampuan verbal $\left(\mathrm{A}_{\mathrm{i}}\right)$, yang dibedakan menjadi tiga kelompok kategori, yaitu tinggi $\left(A_{1}\right)$, sedang $\left(A_{2}\right)$ dan rendah $\left(\mathrm{A}_{3}\right)$.

Penelitian ini dilakukan di SMP Negeri 20 Pekanbaru tahun ajaran 2019/2020 dengan materi pokok pembelajaran relasi dan fungsi. Populasi dalam penelitian ini adalah seluruh siswa kelas VIII yang terdiri dari sembilan kelas. Sedangkan sampelnya adalah kelas VIII.1 sebagai kelas eksperimen dan kelas VIII.4 sebagai kelas kontrol yang masing-masing kelas berjumlah 35 orang siswa, sampel diambil dengan menggunakan teknik Cluster Sampling.

Sebelum dilakukan pengambilan sampel, maka seluruh anggota populasi diberikan pretest. Kemudian datanya di uji normalitas, uji homogenitas dan uji Anova satu arah (one way Anova).
Hasilnya diperoleh bahwa tidak terdapat perbedaan rata-rata kemampuan pemecahan masalah matematis antara sembilan kelas. Sehingga pengambilan sampel dari sembilan kelas tersebut dapat dilakukan secara acak.

Bentuk instrumen yang digunakan dalam penelitian ini berupa tes objektif pilihan ganda untuk mengukur kemampuan verbal siswa yang diadopsi dari tes kemampuan akademik, dengan tujuan untuk mengelelompokkan kemampuan verbal menjadi tiga kategori yaitu tinggi, sedang dan rendah.

Selanjutnya tes uraian digunakan untuk mengukur kemampuan pemecahan masalah matematis siswa sebelum adanya perlakuan (pretest) dan setelah adanya perlakuan (posttest). Tujuan dari pretest adalah untuk mengetahui rata-rata awal kemampuan pemecahan masalah matematis siswa dan sebagai uji populasi syarat pengambilan sampel. Sedangkan tujuan posttest adalah menguji hipotesis untuk menjawab rumusan masalah penelitian. 
Sebelum instrumen ini digunakan untuk memperoleh data penelitian maka peneliti telah melakukan validasi instrumen kepada ahlinya dan juga uji kelayakan, yaitu uji validitas, uji reliabilitas, uji tingkat kesukaran dan uji daya pembeda. Sedangkan untuk tes objektif pilihan ganda dilanjutkan dengan uji efektivitas pengecoh.

Teknik analisis data yang digunakan untuk menguji hipotesis penelitian yaitu menggunakan uji Anova dua arah (two-way Anova). Sebelum data dianalisis menggunakan uji Anova dua arah, maka data yang telah diperoleh dilakukan uji prasyarat analisis data yaitu uji normalitas dan uji homogenitas.

\section{HASIL DAN PEMBAHASAN}

Setelah data kemampuan verbal siswa diperoleh, maka selanjutnya dilakukan analisis. Berdasarkan data yang diperoleh bahwa nilai rata-rata kemampuan verbal siswa $(64,7)$ dan standar deviasinya $(11,04)$. Selanjutnya kemampuan verbal siswa dilakukan pengelompokkan menjadi tiga kategori yang disajikan pada Tabel 2.

Tabel 2. Pengelompokkan kemampuan verbal

\begin{tabular}{cc}
\hline Nilai Interval & Kategori \\
\hline $76 \leq x$ & Tinggi \\
$54<x<76$ & Sedang \\
$x \leq 54$ & Rendah \\
\hline
\end{tabular}

Pengelompokkan ini dilakukan untuk mengetahui kemampuan siswa dalam menyelesaikan soal pemecahan masalah berdasarkan tingkat kemampuan verbal yang dimilikinya. Adapun hasil nilai rataan kemampuan pemecahan masalah matematis siswa yang diberikan sebelum adanya perlakuan (pretest) dan setelah adanya perlakuan (posttest) dikelas eksperimen dan kontrol disajikan dalam bentuk diagram pada Gambar 1.

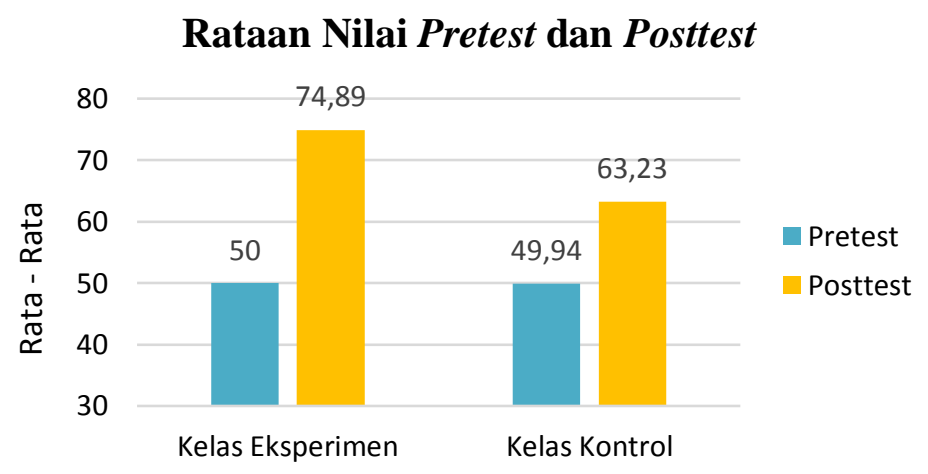

Gambar 1. Nilai rata-rata kemampuan pemecahan masalah matematis

Berdasarkan data pada Gambar 1 bahwa nilai rataan pretest kemampuan pemecahan masalah matematis siswa kelas eskperimen (VIII.1) dan kontrol (VIII.4) memiliki kesamaan rata-rata. Hal ini berdasarkan hasil uji Anova satu arah sebelumnya dari sembilan kelas dengan menggunakan bantuan Software SPSS, diperoleh bahwa sig $=0,952>\alpha$
$=0,05$. Sehingga artinya tidak terdapat perbedaan kemampuan pemecahan masalah matematis siswa dikelas eksperimen dan kontrol sebelum diberikan perlakuan. Seperti yang dikemukakan oleh Sugiyono (2018) bahwa jika setiap semua kelompok memperoleh nilai pretest yang sama 
DOI: https://doi.org/10.24127/ajpm.v9i4.3185

maka kelompok kelompok tersebut dinyatakan baik untuk penelitian.

Namun setelah kelas eksperimen diberikan perlakuan dengan menerapkan model pembelajaran MMP dan kelas kontrol menerapkan model pembelajaran langsung, maka nilai ratarata kemampuan pemecahan masalah matematis siswa menjadi meningkat. Selanjutnya nilai rataan kemampuan pemecahan masalah matematis (posttest) siswa dikelompokkan berdasarkan tingkat kemampuan verbalnya untuk menguji hipotesis dalam penelitian ini, seperti disajikan pada Tabel 3.

Tabel 3. Nilai rataan posttest berdasarkan tingkat kemampuan verbal.

\begin{tabular}{ccccc}
\hline \multirow{2}{*}{ Model pembelajaran } & \multicolumn{3}{c}{ Kemampuan verbal } & \multirow{2}{*}{$\sum$} \\
\cline { 2 - 4 } & $\mathbf{A}_{\mathbf{1}}$ & $\mathbf{A}_{\mathbf{2}}$ & $\mathbf{A}_{\mathbf{3}}$ & \\
\hline Model MMP $\left(\mathrm{B}_{1}\right)$ & 92,83 & 74,83 & 57,17 & 74,89 \\
Pembelajaran langsung $\left(\mathrm{B}_{2}\right)$ & 81,33 & 62,4 & 53 & 63,23 \\
$\sum$ & 87,08 & 69,05 & 54,67 & \\
\hline
\end{tabular}

Sebelum data posttest tersebut dianalisis dengan uji anova dua arah maka terlebih dahulu dilakukan uji prasyarat yaitu uji normalitas dan uji homogenitas. Adapun hasil perhitungan uji normalitas data posttest menggunakan rumus Chi kuadrat dapat dilihat pada Tabel 4.

Tabel 4. Hasil uji normalitas posttest

\begin{tabular}{cccc}
\hline Model pembelajaran & $\chi^{2}$ hitung & $\chi^{2}$ tabel & Keputusan \\
\hline Model MMP $\left(\mathrm{B}_{1}\right)$ & 4,54 & 11,070 & Normal \\
Pembelajaran langsung $\left(\mathrm{B}_{2}\right)$ & 3,78 & 11,070 & Normal \\
\hline
\end{tabular}

Karena masing-masing nilai

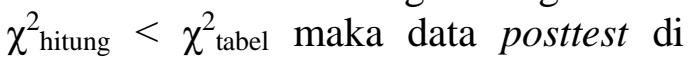
kelas eksperimen $\left(\mathrm{B}_{1}\right)$ dan kelas kontrol $\left(\mathrm{B}_{2}\right)$ berdistribusi normal. Selanjutnya dilakukan perhitungan uji homogenitas data posttest menggunakan uji-F yang disajikan pada Tabel 5.

Tabel 5. Hasil uji homogenitas posttest

\begin{tabular}{ccc}
\hline Kelas & Jumlah Siswa & Varians \\
\hline B1 & 35 & 238,641 \\
B2 & 35 & 301,647 \\
\hline
\end{tabular}

$$
F_{\text {hitung }}=\frac{\sigma^{2} \max }{\sigma^{2} \min }=\frac{301,647}{238,641}=1,264
$$

Nilai varians terbesar yaitu dikelas kontrol, maka $\mathrm{dk}$ pembilang $=34$ dan varians terkecil dikelas eksperimen, maka dk penyebut $=34$. Sehingga pada taraf signifikan 5\%, diperoleh $F_{\text {tabel }}=$ 1,77. Dimana $F_{\text {hitung }}=1,264<F_{\text {tabel }}=$ 1,77 maka data postest untuk kelas eksperimen dan kelas kontrol memiliki varians yang homogen. Karena data posttest telah memenuhi asumsi uji statistik parametrik, maka uji hipotesisnya dilakukan dengan menggunakan uji Anova dua arah, yang hasil perhitungannya disajikan pada Tabel 6.

Tabel 6. Hasil uji Anova dua arah

\begin{tabular}{cccc}
\hline Sumber Varians & $\mathbf{F}_{\text {hitung }}$ & $\mathbf{F}_{\text {tabel }}$ & Keputusan \\
\hline Antar kolom (A) & 17,08 & 3,14 & $\mathrm{H}_{\mathrm{o}}$ ditolak \\
Antar baris (B) & 11,59 & 3,99 & $\mathrm{H}_{\mathrm{o}}$ ditolak \\
Inter AxB & $-0,65$ & 3,14 & $\mathrm{H}_{\mathrm{o}}$ diterima \\
\hline
\end{tabular}


Berdasarkan data hasil uji anova dua arah pada Tabel 6 dapat diuraikan hasil uji hipotesis yaitu pertama, dari hasil perhitungan dengan menggunakan uji Anova dua arah antar baris, diperoleh $\mathrm{F}_{(\mathrm{B}) \text { hitung }}=11,59>\mathrm{F}_{(\mathrm{B}) \text { tabel }}=$ 3,99 dengan taraf signifikan 5\%, maka $\mathrm{H}_{\mathrm{o}}$ yang berbunyi "tidak terdapat perbedaan kemampuan pemecahan masalah matematis antara siswa yang mengikuti model pembelajaran MMP dengan siswa yang mengikuti model pembelajaran langsung" ditolak. Dengan demikian dapat disimpulkan bahwa terdapat perbedaan kemampuan pemecahan masalah matematis antara siswa yang mengikuti model pembelajaran MMP dengan siswa yang mengikuti model pembelajaran langsung. Temuan ini sejalan dengan hasil penelitian terdahulu yang dilakukan Riski Utami Sari dkk, bahwa terdapat perbedaan kemampuan siswa dalam menyelesaikan soal cerita matematika antara yang mengikuti model pembelajaran MMP dengan yang mengikuti model pembelajaran konvensional (Sari, Dantes, \& Ardana, 2014).

Hal ini dapat dilihat dari nilai rataan kemampuan pemecahan masalah matematis siswa yang mengikuti model pembelajaran MMP $(74,89)$ lebih tinggi dari pada siswa yang mengikuti model pembelajaran langsung $(63,23)$. Jika suatu perlakuan yang diberikan berpengaruh secara signifikan apabila kelompok eksperimen dan kelompok kontrol terdapat perbedaan yang signifikan. Selain itu jika kelompok treatment lebih baik dari pada kelompok kontrol maka perlakuan yang diberikan pada kelompok treatment berpengaruh positif (Sugiyono, 2018). Sehingga kesimpulan yang diperoleh dari penelitian ini yaitu terdapat pengaruh yang positif dan signifikan model pembelajaran MMP terhadap kemampuan pemecahan masalah matematis siswa. Sejalan dengan hasil penelitian terdahulu yang dilakukan Rahmiati dan Fahrurrozi bahwa pembelajaran MMP berpengaruh positif dan signifikan terhadap kemampuan pemecahan masalah (Rahmiati \& Fahrurrozi, 2016).

Hal ini dikarenakan dalam kegiatan pembelajaran dengan menerapkan model MMP pada setiap pertemuannya guru memberikan siswa penugasan guna melatih pemahaman siswa terhadap materi pelajaran untuk diterapkan dalam memecahkan masalah berupa lembar tugas proyek, yang diberikan sebanyak tiga kali diantaranya pada tahap belajar kooperatif/terkontrol, pada langkah seatwork secara mandiri dan penugasan yang berupa PR untuk dikerjakan dirumah.

Dengan latihan-latihan soal yang diberikan tersebut bisa membantu siswa untuk terampil dan meningkatkan kemampuannya dalam memecahkan masalah matematis. Seperti yang dikemukakan oleh Indah Mawarni Gafur, dkk bahwa untuk dapat memperoleh kemampuan pemecahan masalah, seseorang itu harus memiliki pengalaman dalam memecahkan berbagai masalah (Gafur, Sudia, \& Hasnawati, 2015).

Proses kegiatan pembelajaran dengan menggunakan model MMP ini dirancang agar siswa mampu menyelesaikan masalah matematis dengan cara terampilnya menyelesaikan latihan-latihan soal baik secara mandiri dan diskusi kelompok. Selain itu adapun kelebihan dari model pembelajaran MMP diantaranya adalah waktu yang digunakan dalam proses pembelajaran diatur secara ketat sehingga materi yang diajarkan tersampaikan sepenuhnya kepada siswa, dan banyak latihan- 
latihan sehingga siswa bisa terlatih dalam menyelesaikan berbagai macam soal pemecahan masalah (Rahmiati \& Fahrurrozi, 2016).

Berdasarkan fakta yang terjadi dikelas selama melaksanakan model pembelajaran ini bahwa tidak terjadinya kekurangan waktu dalam proses pembelajaran, tentunya materi yang disampaikan dan evaluasi yang diberikan terlaksana secara maksimal untuk mentransfer pengetahuan dan pengalaman kepada siswa. Sehingga penerapan model pembelajaran ini mendapatkan pengaruh yang positif dalam rangka meningkatkan kemampuan siswa untuk memecahkan masalah matematis. Adanya kegiatan diskusi kelompok dalam model pembelajaran ini juga memberikan kesempatan kepada siswa untuk menyampaikan ide-ide dan saling bertukar fikiran bersama temantemannya untuk menyelesaikan lembar tugas proyek yang diberikan.

Sehingga untuk siswa yang memiliki prestasi belajar yang rendah dan malu untuk bertanya kepada gurunya yang berkaitan denganmateri pembelajaran bisa bertanya kepada temannya atau anggota kelompoknya. Hal ini sesuai dengan yang dikemukakan oleh Ansori dan Aulia bahwa model pembelajaran MMP adalah salah satu model pembelajaran yang mampu meningkatkan kemampuan siswa dalam memecahkan masalah matematis (Ansori \& Aulia, 2015).

Kedua, berdasarkan hasil perhitungan dengan uji Anova dua arah antar kolom diperoleh bahwa $\mathrm{F}_{(\mathrm{A}) \text { hitung }}=$ $17,077>\mathrm{F}_{(\mathrm{A}) \text { tabel }}=3,14$ dengan taraf signifikan $5 \%$, maka $\mathrm{H}_{\mathrm{o}}$ yang berbunyi "tidak terdapat perbedaan kemampuan pemecahan masalah matematis antara siswa yang memiliki kemampuan verbal tinggi, sedang dan rendah" ditolak.
Dengan demikian dapat disimpulkan bahwa terdapat perbedaan kemampuan pemecahan masalah matematis antara siswa yang memiliki kemampuan verbal tinggi, sedang dan rendah. Sehingga dengan kata lain bahwa terdapat pengaruh kemampuan verbal terhadap kemampuan pemecahan masalah matematis. Hasil temuan ini sejalan dengan hasil penelitian terdahulu yang dilakukan Dewi Surani bahwa terdapat pengaruh kemampuan verbal (tinggi, sedang dan rendah) siswa terhadap kemampuan pemecahan masalah matematis (Surani, 2018).

Berdasarkan perolehan nilai rataan kemampuan pemecahan masalah matematis siswa yang memiliki kemampuan verbal tinggi $(87,08)$, sedang $(69,05)$ dan rendah $(54,67)$, terlihat bahwa semakin tinggi tingkat kemampuan verbal siswa maka kemampuan pemecahan masalah matematis siswa juga makin meningkat. Seperti yang dikatakan oleh Wahyuddin dari hasil penelitiannya bahwa semakin tinggi kemampuan verbal siswa maka semakin tinggi juga kemampuannya dalam menyelesaikan soal cerita (Wahyuddin, 2016).

Hal ini disebabkan karena untuk bisa menyelesaikan suatu masalah matematis maka perlunya pemahaman terhadap masalah yang diberikan, yang meliputi memahami komponen yang diketahui dan yang ditanyakan, memahami bentuk rencana pemecahan masalah yang sesuai, memahami cara menyelesaikan rencana pemecahan masalah dan menentukan solusi yang tepat dengan pertanyaan yang diberikan. Sehingga dengan adanya kemampuan verbal ini siswa memiliki peluang untuk dapat menyelesaikan masalah matematis dengan baik dan benar. Wahyuddin juga mengemukakan bahwa terdapat pengaruh positif kemampuan verbal terhadap kemampuan 
menyelesaikan soal cerita, dengan pengaruh sebesar 42\%, sedangkan sisanya dipengaruhi oleh variabel lain (Wahyuddin, 2016).

Namun jika dilihat dari penerapan model pembelajarannya, siswa pada kelompok kemampuan verbal tinggi yang mengikuti model pembelajaran MMP memiliki nilai rataan kemampuan pemecahan masalah matematis $(92,83)$, siswa yang berkemampuan verbal sedang $(74,83)$ dan siswa yang berkemampuan verbal rendah $(57,17)$. Sedangkan nilai rataan kemampuan siswa dalam memecahkan masalah matematis yang mengikuti model pembelajaran langsung pada kelompok kemampuan verbal tinggi $(81,33)$, siswa berkemampuan verbal sedang $(62,4)$ dan berkemampuan vebal rendah (53).

Dapat dilihat bahwasannya nilai rataan pemecahan masalah siswa dikelas eksperimen dan kelas kontrol mengalami peningkatan yang sama berdasarkan tingkat kemampuan verbalnya. Namun pengaruh kemampuan verbal terhadap kemampuan pemecahan masalah matematis siswa yang mengikuti model pembelajaran MMP lebih baik dari pada siswa yang mengikuti model pembelajaran langsung. Seperti hasil penelitian terdahulu yang dilakukan oleh Riski Utami Sari, dkk bahwa kemampuan siswa dalam menyelesaikan soal cerita matematika yang memiliki kemampuan verbal tinggi dan mengikuti model pembelajaran MMP lebih baik dari pada siswa yang mengikuti model pembelajaran langsung (Sari, Dantes, \& Ardana, 2014).

Hal ini karena kemampuan verbal sejalan dengan tujuan dari model pembelajaran MMP, yaitu menuntun siswa disetiap langkahnya untuk belajar memahami bacaan dan penjelasan, menjelaskan dan belajar untuk mandiri. Sedangkan model pembelajaran langsung, siswa berperan hanya sebagai pendengar yang pasif terhadap materi pelajaran yang disampaikan guru. Hal tersebut menyebabkan siswa merasa bosan mengikuti proses pembelajaran. Sehingga akibatnya siswa tidak bisa memahami materi yang disampaikan oleh guru. Pada akhirnya kemampuan pemecahan masalah matematis siswa pun menjadi rendah. Sehingga dapat disimpulkan bahwa kemampuan verbal berpengaruh terhadap kemampuan pemecahan masalah matematis siswa.

Ketiga, berdasarkan hasil perhitungan uji Anova dua arah antar kolom dan baris diperoleh $\mathrm{F}_{(\mathrm{AxB}) \text { hitung }}=$ $0,651<\mathrm{F}_{(\mathrm{AxB}) \text { tabel }}=3,14$ dengan taraf signifikan $5 \%$, maka $\mathrm{H}_{\mathrm{o}}$ yang berbunyi "tidak terdapat interaksi antara model pembelajaran dan kemampuan verbal terhadap kemampuan pemecahan masalah matematis siswa" diterima. Dengan demikian dapat disimpulkan bahwa tidak terdapat interaksi antara model pembelajaran dan kemampuan verbal terhadap kemampuan pemecahan masalah matematis siswa. Temuan hasil penelitian ini relevan dengan hasil penelitian terdahulu bahwa model pembelajaran dan kemampuan verbal peserta didik tidak terdapat interaksi terhadap kemampuan pemecahan masalah matematika (Surani, 2018).

Sehingga pengaruh model pembelajaran terhadap kemampuan pemecahan masalah matematis tidak tergantung pada kemampuan verbal, begitu juga pengaruh kemampuan verbal terhadap kemampuan pemecahan masalah matematis tidak tergantung pada model pembelajaran. Sehingga model pembelajaran dan kemampuan verbal memiliki pengaruh yang terpisah terhadap kemampuan pemecahan masalah matematis. 


\section{KESIMPULAN DAN SARAN}

Berdasarkan hasil analisis data, maka kesimpulan yang diperoleh dari hasil penelitian ini adalah: 1) Terdapat pengaruh yang positif dan signifikan penerapan model pembelajaran MMP terhadap kemampuan pemecahan masalah matematis siswa, 2) Terdapat pengaruh kemampuan verbal terhadap kemampuan pemecahan masalah matematis siswa, 3) Tidak terdapat interaksi antara model pembelajaran dan kemampuan verbal terhadap kemampuan pemecahan masalah matematis siswa.

Adapun saran yang dapat diberikan yaitu untuk meningkatkan kemampuan siswa dalam memecahkan masalah matematis, maka guru atau peneliti perlu memilih model pembelajaran yang kegiatannya sesuai dengan tujuan yang diharapkan, salah satu alternatifnya adalah model MMP. Dampak yang diperoleh dari hasil penelitian ini yaitu respon yang diberikan siswa dalam kegiatan pembelajaran bisa lebih terarah dan menyempurnakan kemampuan siswa dalam memecahkan masalah matematis, karena meninjau berdasarkan aspek kemampuan verbalnya.

\section{DAFTAR PUSTAKA}

Ansori, H., \& Aulia, I. (2015). Penerapan Model Pembelajaran Missouri Mathematics Project (MMP) terhadap Kemampuan Pemecahan Masalah Siswa di SMP. Jurnal Pendidikan Matematika, 3(1), 49-58.

Gafur, I. M., Sudia, \& Hasnawati. (2015).

Meningkatkan

Kemampuan Pemecahan Masalah Open Ended Siswa Kelas VII-2 SMPN 3 Kulisusu melalui Pendekatan Pengajuan Masalah pada Pokok Bahasan
Segi Empat. Jurnal Penelitian Pendidikan Matematika, 3(1), 75-90.

Hendriana, H., Rohaeti, E., \& Sumarmo, U. (2017). Hard Skills dan Soft Skills Matematik Siswa. Bandung: PT Refika Aditama.

Irawan, A., \& Kencanawaty, G. (2016). Peranan Kemampuan Verbal dan Kemampuan Numerik terhadap Kemampuan Berfikir Kritis Matematika. AKSIOMA: Jurnal Program Studi Pendidikan Matematika, 5(2), 110-119.

James, \& Adewale. (2010). Relationship between senior secondary schools students achievement in mathematical problem-solving and intellectual abilities tests. European Scientific Journal, 8(15), 25-53.

Kemdikbud, P. W. (2019). Hasil PISA Indonesia 2018. Retrieved from https:// kemdikbud.go.id

Komariya, Farida, N., \& Vahlia, I. (2018). Pengaruh Model Pembelajaran FSLC terhadap Kemampuan Pemecahan Masalah Matematika ditinjau dari Motivasi Belajar Siswa. AKSIOMA: Jurnal Program Studi Pendidikan Matematika, 7(1), 96-102.

Pembelajaran, P. A. (2019). Tentang PISA. Retrieved from https://puspendik.kemdikbud.go. id

Rahmiati, \& Fahrurrozi. (2016). Pengaruh Pembelajaran Missouri Mathematics Project terhadap Kemampuan Pemecahan Masalah 
DOI: https://doi.org/10.24127/ajpm.v9i4.3185

Matematika. Jurnal Pendidikan Matematika, 10(2), 1-12.

Riska, \& Amir, Z. (2018). Kemampuan Pemecahan Masalah Matematis dengan Model Pembelajaran Cooperative Integrated Reading and Composition (CIRC) ditinjau dari Kemampuan Awal Matematis siswa. Journal of Medives, 2(2), 225-233.

Risnawati, \& Amir, Z. (2015). Psikologi Pembelajaran Matematika. Yogyakarta: Aswaja Pressindo.

Sari, R. U., Dantes, \& Ardana. (2014). Pengaruh Model Pembelajaran Missouri Mathematics Project terhadap Kemampuan Menyelesaikan Soal Cerita Matematika ditinjau dari Kemampuan Verbal. E-Journal Program Pascasarjana Universitas Pendidikan Ganesha, 4, 1-11.

Sugiyono. (2018). Metode Penelitian Kuantitatif, Kualitatif dan $R \& D$. Bandung: Alfabeta.

Surani, D. (2018). Pengaruh Model Pembelajaran Kooperatif Tipe Pair Check Terhadap Kemampuan Pemecahan Masalah Matematika ditinjau dari Kemampuan Verbal Peserta Didik Kelas VII SMPN 1 Sidomulyo. Skripsi. Retrieved from http://repository.radenintan.ac.id /4458/

Tiasto, R. H., \& Arliani, E. (2015). Model Pembelajaran Missouri Mathematics Project (MMP) dengan Metode Two Stay Two Stray. Seminar Nasional Matematika dan Pendidikan Matematika UNY, 1191-1198.
Wahyuddin. (2016). Analisis Kemampuan Menyelesaikan Soal Cerita Matematika ditinjau dari Kemampuan Verbal. Jurnal Tadris Matematika, 9(2), 148160.

Wulandari, T., \& Ansori, H. (2013). Pengaruh Model Pembelajaran Missouri Mathematics Project terhadap Kemampuan Siswa dalam Memecahkan Masalah. Jurnal Pendidikan Matematika, 1(1), 76-81. 